\title{
The Joint-Decision Trap Revisited
}

\section{MPIfG Journal Article}

Fritz W. Scharpf: The Joint-Decision Trap Revisited. In: Journal of Common Market Studies 44(4), 845 - 864 (2006). Wiley-Blackwell The original publication is available at the publisher's web site: http://dx.doi.org/10.1111/j.1468-5965.2006.00665.x

The MPIfG Journal Articles series features articles by MPIfG researchers and visiting scholars published in peer-reviewed journals. Max Planck Institute for the Study of Societies (MPIfG) Cologne | www.mpifg.de

FRITZ W. SCHARPF

Max-Planck-Institut für Gesellschaftsforschung

\begin{abstract}
The original analysis appears as a basically valid - if simplified - account of the institutional conditions of political policy choices in the EU and their consequences. It needs to be complemented, however, by a similar account of non-political policymaking in the supranational-hierarchical mode of governance by the ECB or ECJ.
\end{abstract}

\section{Introduction: A Successfully Deficient Contribution}

In re-reading the 'Joint-Decision Trap' (1988), I find it worth noting that the text is older than it seems. The original manuscript was written in 1983-84 for a study group of the Western Europe Committee of the American Social Science Research Council. Headed by Philippe Schmitter, the group was supposed to reflect on some vague and ambitious theme like 'Reconstituting the Boundaries of the Political'. I had been co-opted to write something about recent changes in German federalism, but Schmitter suggested that I should also explore possible parallels in European integration - a subject which, until that time, had not been among my academic concerns. Since the edited volume which the group was to produce was not yet in sight, I published a German version of my essay in 1985 which was followed by an Italian translation in 1986. By 1988, when the edited volume had finally evaporated altogether, I agreed to have a slightly amended version of the original English text published by Public Administration. 
This genesis suggests that the article should have suffered from three limitations. First, it was shaped by the excitement of a neophyte exploring a new field. Second, it was drafted well before the Single European Act and the success of the single market programme, let alone monetary union, would have empirically disturbed the stark simplicity of the original sketch. Finally, it was written from a German perspective, highlighting the characteristics of European integration that I could see from that vantage point. As it turned out, however, some of these deficiencies actually contributed to the apparent success of the article on the citation index.

In itself, the fact that the European Community was approached from the study of German federalism implied a comparative perspective that avoided the sui generis premises that had tended to isolate the work on European integration from the mainstream of political science research and theory. Instead, the article suggested that the European polity might be usefully compared to the institutions and politics of federal nation-states - an idea which has since developed into an important strain in the Europeanist literature (Sbragia, 1993; Nicolaïdis and Howse, 2001). In fact, however, my original research on Germany had focused more narrowly on the consequences of policy-making through intergovernmental negotiations - which we had originally discussed and explained in the framework of Coasian negotiation theory (Scharpf et al., 1976). Hence the comparison was also focused on intergovernmental negotiations at the European level, and the article tried to show that some of the manifest failures of German and European policy could be explained by the same negotiation-theoretic hypotheses. Compared to more holistic treatments of European integration, therefore, the narrow empirical focus of my contribution made it more amenable to the application of an explanatory model derived from general theory. ${ }^{1}$

Given the purposes of the article and the context in which it was drafted, the model was presented in a rudimentary and informal fashion. But the more precise specification of the 'joint-decision trap' (or what I later called a 'compulsory negotiation system') and its consequences proved to be quite straightforward (Scharpf, 1997) - and very much in line with George Tsebelis' analyses of the policy implications of 'veto players systems' (Tsebelis, 1995, 2002).

Yet even though it was intended to focus on a particular aspect of policymaking, the article was sometimes read as if it were meant as a comprehensive representation of the workings of the German political system or of the

\footnotetext{
${ }^{1}$ That I was not primarily interested in explaining European integration as such is also demonstrated by the concluding section which tries to specify the abstract conditions of a 'joint-decision trap' and suggests some possible applications of the model in constellations as diverse as self-governing university faculties, joint ventures, or political coalitions (Scharpf, 1988, pp. 271-3).
} 
European Community. For Germany, such over-extended interpretations were relatively rare and generally innocuous: most readers knew that not all policy areas were caught in the federal joint-decision trap - some were obviously governed in a mode of neo-corporatist concertation between the government and large interest organizations, others evolved in common-law fashion under the guidance of specialized labour or administrative courts, and some were indeed shaped by the politics of parliamentary majorities (Katzenstein, 1987; Schmidt, 2003; Hesse and Ellwein, 2004).

With regard to Europe, however, the article's ranking on the citation index was significantly enhanced by interpretations that ignored its intended domain. For authors reporting empirical work, it became a must citation in the introductory discussion of theories which they would then proceed to 'falsify' by their own findings. Worse yet, the article was conscripted in the ontological battle that 'intergovernmentalists' and 'supranationalists' were waging over the true nature of the European polity. On this front, I saw no reason to take sides. Since my later work focused on the political economy and legitimacy of European policy, my view of the institutional framework of European policy-making had become too complex for simple dichotomies.

If pushed to present a greatly simplified model of the overall conditions shaping policy processes in the European Union, I would now insist on the co-existence of at least three distinct modes of European governance - which I have recently described as the 'intergovernmental' mode, the 'joint-decision' mode, and the 'supranational-hierarchical' mode (Scharpf, 2001). Of these, only the first and, arguably, the second were treated in the 'Joint-Decision Trap' in an analysis which still appears to me as an empirically valid application of Coasian negotiation theory under institutional conditions constituting an extreme variant of a multiple-veto player system. I will begin with a brief restatement of what I consider the still valid arguments and then proceed to a discussion of what is missing.

\section{The Intergovernmental Mode: An Exercise in Applied Negotiation Theory}

In Germany as in the European Community/Union, important policy choices at the centre, and also all institutional changes, depend on the support of constituent governments (of the Länder or Member States) either by unanimous agreement or by qualified majority votes. In contrast to the ideological or class-based factions of national parliaments, the Bundesrat and the Council of Ministers are supposed to represent territorially-based interests. But unlike the US Senate and the second chambers of all other parliamentary federal states, their members will not only represent the interests of citizens and firms in their respective territories, but are also able to defend directly the institutional 
self-interests of their governments. This makes it useful to distinguish between substantive policy choices and changes in the institutional architecture of these multi-level polities.

For substantive policy, the Coase theorem postulates that, in the absence of transaction costs, and with side-payments and package deals universally available, all potential welfare gains which a benevolent and omniscient dictator might provide could also be realized by negotiations between self-interested and fully informed individual actors (Coase, 1960). But of course, transaction costs are far from zero; side-payments and package deals are often not feasible; and even if they were, complete information about the true preferences, constraints and alternative options of all other participants would be very hard to come by. If agreement depends on 'all-channel negotiations', moreover, these difficulties would exponentially increase with the number of independent participants. Hence it was safe to conclude that, as an empirical matter, selfinterested bargaining between the German Länder, or between the Member States of the European Community, was likely to generate sub-optimal policy outcomes - resulting either in blockages or in inefficient lowest-denominator compromises.

From the normative perspective of liberal political theorists, that may not seem so bad. Their strong preference for unanimous decisions (Buchanan and Tullock, 1962) presupposes that agreements that are in fact reached are welfareimproving, since all participants must prefer the outcome to the status quo, whereas the liberty of individual action will continue to prevail if negotiations should fail. But that assumption holds only for 'voluntary negotiation systems' and when negotiators are still writing on a clean slate. But Germany as well as the European Community are 'compulsory negotiation systems' where certain purposes can be realized only through agreement (Scharpf, 1997). In any case, moreover, once a binding rule is agreed upon, individual action is no longer permitted, and the veto of one or a few governments will prevent all others from correcting or abolishing the rule in response to changed circumstances or preferences. Hence, as negotiating systems with multiple veto players come to accumulate a growing acquis communautaire, they will progressively lose the capacity for policy innovation (Tsebelis, 1995, 2002).

The obvious remedy would be a change from unanimous decisions to simple majority voting - the one decision rule that does not discriminate between the defenders of the status quo and the promoters of policy reform. In Germany, the constitution would in fact allow this in many cases. ${ }^{2}$ But in the absence of strong party-political pressures, the Länder have always tried to achieve near

\footnotetext{
${ }^{2}$ For most legislation, absolute majorities in the Bundesrat are required. Abstentions count as no votes, and since coalition governments often abstain, blocking minorities may actually be quite small.
} 
unanimity in order to present a united front vis-à-vis the federal government (Scharpf et al., 1976). In Europe, simple majority voting on politically salient issues would in my view lack legitimacy (Scharpf, 1999, 2003). In any case, the best that could so far be achieved has been qualified majority voting on many, but by no means all issues - and even after the reforms adopted at Nice, these would still require a very high quorum of two-thirds of the votes in the Council (Tsebelis and Yataganas, 2002). Moreover, as in Germany, EU governments have generally been searching for consensus and avoiding decisions that would violate the vital interests of a Member State (Hayes-Renshaw et al., 2006).

In the original article, I used the metaphor of the 'joint-decision trap' to summarize the arguments explaining these practices. They start from the fact that, on issues of institutional reform, member governments represent not only the interests of their constituents but also their own institutional self-interest which, in the present context, can be interpreted as a concern for autonomy and influence. If problems within their territories can no longer be resolved through autonomous policy choices, these governments may reluctantly delegate competencies to higher-level institutions. But they will nevertheless try to maintain as much influence as possible over the exercise of these competencies. In order to prevent decisions violating their own preferences, they will insist on unanimity or qualified majority voting even though the outcomes are likely to be inefficient from a problem-solving perspective.

Assuming that a move to simple majority voting will not be feasible, the article then explores the possibility that the 'style' of self-interested bargaining might be replaced by solidaristic 'problem-solving'. The underlying intuition, which anticipated the theoretical concept of the 'negotiator's dilemma' (Lax and Sebenius, 1986), is that many or most of the interest constellations involved in intergovernmental negotiations at the European level are in the nature of 'mixed-motive games'. Such constellations may be analytically disaggregated into a common interest in producing the welfare gains that can only be achieved through co-operation, and conflicting interests in the distribution of benefits and costs. If, under these conditions, both types of interest must be pursued simultaneously, bona fide co-operators are likely to be exploited by free riders maximizing distributive gains. In theory, this dilemma could be overcome either by a procedural separation of co-operative problem-solving from distributive bargaining or by a solidaristic transformation of preferences (Scharpf, 1997) - a possibility which has subsequently come to fascinate the 'constructivist' school of European studies (Christiansen et al., 1999; Checkel, 1999). ${ }^{3}$

\footnotetext{
${ }^{3}$ Transaction costs may also be reduced by increasing empathy among negotiators. National officials located permanently in Coreper, the Council Secretariat and the Brussels staffs of national ministries may come to appreciate each others' positions, and to seek solutions that will not violate highly salient national concerns (Hayes-Renshaw and Wallace, 1997; Lewis 2003). 


\section{Transaction Costs Reduced in the Joint-Decision Mode}

With hindsight, however, I am embarrassed to have ignored the Commission's potential role in reducing the transaction costs of consensual policy solutions through its monopoly of legislative initiative. This mechanism is central to what I now call the 'joint-decision mode' and what the Commission likes to call the 'Community method'. In order to appreciate its consensus-facilitating power in comparison to pure intergovernmental bargaining, one needs to consider the exponential rise of complexity (and hence transaction costs) in all-channel negotiations that are trying to reach agreement on welfare-maximizing (or 'problem-solving') policy solutions:

In all-channel negotiations between $(N)$ veto players, each of whom is trying to protect $(a)$ salient concerns, one would need $\left[N \cdot(N-1) \cdot a^{2}\right]$ bilateral examinations of policy impacts in order to identify potentially consensual policy choices (Friend and Jessop, 1969; Scharpf, 1972). However, if solutions could be proposed by a single, central agent, that agent would need to explore only $(N \cdot$ a) policy impacts to develop a win-win solution which (if the solution space is not empty!) should be acceptable to all veto players.

In the real world, this possibility of 'intelligent design' may allow the Commission to present creative proposals that go beyond the trivial exploitation of fixed policy preferences suggested by the role of the agenda-setter in spatialvoting theories. ${ }^{4}$ Relying on extensive consultations with interest groups, national and sub-national officials and independent experts, the Commission may be able to assess the hardness or pliability of the interests and constraints defended by all member governments, and to develop innovative win-win solutions which - though departing from the initial policy preferences of some or all veto players - may still be preferred to the status quo by all (or at least a qualified majority of) member governments and a majority in the European Parliament.

That is, of course, not the end of the story, given the unpredictable vagaries of national politics and intergovernmental and inter-institutional group dynamics. Nevertheless, as long as the Commission is accepted as an 'honest broker'

\footnotetext{
${ }^{4}$ It is important to note the difference between the Coasian approach adopted here, and the role of the agenda-setter in spatial voting theory. Coasian theory is welfare theoretic, asking if self-interested bargaining between rational agents could lead to welfare-maximizing policy solutions. The positive answer assumes fixed preferences over outcomes (i.e. 'interests'), but totally flexible preferences over strategies (i.e. 'policies'). In other words, welfare gains in Coasian theory presuppose successful 'policy learning' and the reduction of transaction costs helps to reduce obstacles to policy learning.

Spatial voting theory, in contrast, ignores the possibility of policy learning and takes fixed preferences over strategies ('policies') plus the default outcome in case of non-agreement (usually the status quo) as its point of departure. If the solution space among policy preferences is empty, that is the end of the matter. If not, the 'agenda-setter' gains the power to select its own preferred policy from the feasible set. Obviously, this power is the greater the more the decision rule departs from unanimity (Romer and Rosenthal, 1978; Enelow and Hinich, 1990; Tsebelis, 1994). But it is not welfare increasing.
} 
by the Member States, and as a politically neutral guardian of the European public interest, its agenda-setting role should ensure more successful negotiations than one should expect from strictly intergovernmental bargaining. At the theoretical level, I would thus have to soften the pessimistic implications of the joint-decision trap.

But not by much. Transaction costs still rise with the number of Member States and the diversity of their preferences and, in any case, the good services of the Commission will not help if the solution space is empty - i.e. if problemsolving solutions would require uncompensated sacrifices by at least some participants. In theory, it is true, compensation might be achieved through side payments or through package deals combining asymmetric solutions in different policy areas. But side-payments, which often facilitated European compromises in the past, are increasingly constrained by the EU budget, whereas package deals have always been difficult to achieve in the narrowly specialized councils of ministers. In any case, not all sacrifices can be compensated, and the difficulty of reaching negotiated agreement increases with the heterogeneity of Member State conditions, interests and preferences. Thus while the 'original six' might perhaps have agreed on the European harmonization of their 'Bismarckian' welfare states, the present hope for a common commitment to the 'European social model' was already destroyed with the first enlargement that had brought Britain, Ireland and Denmark into the Community (Scharpf, 2002). On politically salient issues, therefore, transaction cost-reducing mechanisms have been overwhelmed by the increase in numbers of Member States and in their heterogeneity, and the logic of the joint-decision trap must be stronger in the EU-25 today than it was when I wrote about the EC-12 in 1984.

\section{The Supranational-Hierarchical Mode}

If this were all, I could content myself with clarifying the original argument and relating it to theoretical advances in the more recent literature. But if the article is read as an overview of EU governance modes, there is a much more serious gap that has occupied much of my later work on European integration. The jointdecision trap applies to the intergovernmental and joint-decision modes which I discussed. But it does not apply to the supranational-hierarchical mode in which the Commission, the European Court of Justice or the European Central Bank are able to exercise policy-making functions without any involvement of politically accountable actors in the Council or the European Parliament.

This mode of governing was completely ignored in the original article - even though, having previously worked on the policy-making functions of the judiciary myself (Scharpf, 1966), I should have been alerted to it by Joe Weiler's path-breaking analysis of the 'Dual Character of Supranationalism' 
(1982). Its origins go back to the 1960s, when the Court had succeeded, over the feeble opposition of some member governments, in establishing the twin doctrines of the 'supremacy' and the 'direct effect' of European law (Alter, 2001). As a consequence, not only the 'primary law' of the treaties, but also the 'secondary law' of European regulations and directives came to take legal precedence over all national law, including parliamentary legislation, plebiscites, and the national constitution - and since they also had direct effect, European rules could be invoked as the supreme law of the land by any party in legal proceedings before national courts. To become effective, these doctrines depended on the willingness of national courts to accept the decisions and preliminary rulings of the European Court as the authoritative interpretation of European law. Once this condition was secured, however, the power to interpret became a power to legislate that was sanctioned by the respect for the rule of law engrained in the political cultures of Member States (Alter, 1996; de Búrca, 2003; Stone Sweet, 2003).

By itself, of course, the Court's power can be exercised only in cases that happen to come before it, and on issues raised by the parties to these cases. Its strategic value as an instrument of European legislation can thus be appreciated only when it is seen in conjunction with the Commission's mandate to 'ensure that the provisions of this Treaty and the measures taken by the institutions pursuant thereto are applied' (Art. 211, ex. 155 TEC) and its power to bring violations of Treaty obligations by a Member State before the Court (Art. 226, ex. 169 TEC) (Börzel, 2003). Given the Court's power of judicial legislation and its own enforcement powers, the Commission is then able to avail itself of two distinct legislative options.

It may choose the joint-decision mode and propose European regulations or directives that needed to be approved by the Council (and now, the Parliament). But given some of the very sweeping commitments to European economic integration in the original treaties, it may also attempt to legislate in the supranational-hierarchical mode. To do so, it has to assert that a particular rule should have direct effect and that certain laws or practices in Member States are in violation of it. If these arguments are then upheld by the Court, the interpretation will be the law of the land in all Member States without any further action by governments or parliaments at European or national levels.

Compared to the situation in national democracies, moreover, judicial legislation at the European level is also extremely well protected against political correction. If decisions are based on an interpretation of treaty provisions, they could be corrected only through amendments that must be ratified by national parliaments or referendums in all Member States. And it is hardly less difficult to change judicial interpretations of directives and regulations - which would require new legislation that the Commission itself would have to propose, and 
that must be adopted by at least a qualified majority in the Council and in most cases also a majority in the European Parliament. In short, all the obstacles to European political action in the intergovernmental or joint-decision modes will also immunize judicial legislation against political correction.

From my present perspective, therefore, the joint-decision trap appears as a basically valid - though simplified - account of the institutional conditions of political policy choices in the European Union and their consequences. It needs to be complemented, however, by a similar account of the conditions and consequences of non-political European policy-making in the supranationalhierarchical mode. That I did not see that at the time may be excused by the fact that the policy-making potential of this mode had not yet become a fully-fledged reality. The European Central Bank was not even on the horizon of realistic proposals, and while the institutional preconditions of judicial legislation were all in place by 1983-84, the Commission and the Court were only just beginning to discover their strategic usefulness as an instrument of European policy-making that was not caught in the joint-decision trap.

As it happened, this discovery coincided with a neo-liberal window of opportunity in the intergovernmental politics of the EU. In the early 1980s, the recession caused by monetarist responses to the second oil-price crisis was widely interpreted as a symptom of 'eurosclerosis' which the Commission proposed to combat by a widening and deepening of market integration. In order to facilitate the removal of non-tariff barriers and further liberalization, not only traditionally pro-European governments but also Margaret Thatcher's Britain agreed to the Single European Act of 1986 which introduced qualified majority voting in the Council for directives implementing the internal market programme (Moravcsik, 1998). Of course, even qualified majority was still a very high hurdle when existing regulations, public service monopolies and legally protected cartels in the Member States had to be challenged. But by then the Commission's second legislative option had also come into its own.

Starting with the Cassis de Dijon decision of 1979 (ECJ Case 120/78), the Court had signalled its willingness to intervene against national non-tariff barriers even in the absence of harmonizing European legislation. Since the default outcome - the mutual recognition of incompatible national regulations - would often appear undesirable or even impracticable (Schmidt, 2002), the mere threat of Court action would greatly increase the willingness of all governments to accept the minimum harmonization directives proposed by the Commission. In the field of competition policy, moreover, the Commission made strategic use of treaty violation proceedings against the public service monopolies of some Member States - whose governments would then support directives that would open the service and infrastructure functions of all other Member States to market competition (Schmidt, 1998, 2000). And of 
course, each new directive extends the acquis communautaire, i.e. the body of secondary European law which the Commission is bound to enforce and whose interpretations by the Court cannot be reversed politically.

\section{Policy Consequences}

In other words, the combination of judicial legislation and the Commission's monopoly of legislative initiatives was able to increase the effectiveness of European policy-making far beyond the constraints discussed in the jointdecision trap. But it did not and could not do so in all policy areas. Thus when I came to appreciate the power of the supranational-hierarchical mode in the early 1990s, my attention also turned to the substantive policy consequences of the plural governing modes prevailing in the European Union.

My first cut was the distinction between 'negative' and 'positive integration' (Scharpf, 1996). The supranational-hierarchical mode had its strongest base in the economic freedoms and competition rules postulated by the Treaty - which were perfectly suited to support the removal of national regulations considered as non-tariff barriers to trade or as distortions of competition. Quite apart, therefore, from the neo-liberal beliefs of members of the Commission and the Court (Gerber, 1994a, b, 2001), institutional conditions were most favourable to the widening and deepening of market-making, market-extending and market-enhancing European law. In contrast to negative integration, marketcorrecting positive integration depended on political legislation, either in the intergovernmental or the joint-decision mode where very high consensus requirements and the heterogeneity of Member State interests and preferences would make agreement difficult or impossible.

Recognizing, however, that there were some policy areas where the adoption of market-correcting rules was relatively more successful than in others, I attempted to capture the difference by referring to the further distinction between 'product' and 'process regulations'. Under the Treaty, Member States could not be prevented from applying national product standards that served legitimate safety or environmental purposes. Thus at least a minimal harmonization of product standards was essential if the benefits of the internal market were to be realized. By contrast, regulations of production processes, which might affect the cost of the product, but not its quality itself, could not be used to ban imports produced under another national regime. Hence Member States that enjoyed the competitive advantages of lower working and employment standards, or lower taxes on factors or production and business profits, would have no reason to agree to the 'levelling of the playing field' which Member States with more demanding regulations and higher taxes might demand. 
By and large, and with some fuzzy edges, this distinction seemed to work reasonably well. But not all policies can be classified as being either 'product' or 'process' related. From my present perspective, therefore, I would not place so much weight on trying to identify a substantively defined dividing line. Instead, I would once more refer to the underlying logic of general negotiation theory: given an institutional setting with high consensus requirements, positive integration is likely to succeed in policy areas where national interests converge and it will fail in policy areas where divergent national interests and preferences are politically salient. In my 1999 book Governing in Europe (Scharpf, 1999), I tried to classify policy areas according to this criterion, and I think the ordering along the dimension of greater or lesser European capacity to act has held up fairly well.

\section{The European Problem-Solving Gap}

The question which has occupied me more in recent years was what would happen in policy areas where positive European integration seemed unlikely or impossible. The automatic answer is, of course, given by the 'subsidiarity' rule: where Europe cannot act, the Member States remain in charge. But that answer ignores the constraints on national action that are created by the success of European economic and monetary integration. Some of these constraints are of a legal character: many of the policy instruments which Member States had routinely employed to manage their economies in earlier decades - from import controls, export subsidies and the devaluation of national currencies to regional and sectoral subsidies and the strategic use of public procurement and the employment buffers of public-service industries - are no longer available to members of economic and monetary union. At the same time, the free movement of goods, services, capital and labour and the liberalization of public-service industries have created economic constraints on national tax policies and on regulations that might increase the costs of domestic production, reduce the post-tax rates of return of domestic investments, or create incentives for welfare migration (Sinn and Ochel, 2003). Member States that were unable to adjust to these constraints of economic integration would then suffer from declining investment, low economic growth, rising unemployment, higher welfare burdens and public deficits.

But, again, not all national policy areas would be equally affected by the constraints of legal and economic integration - an intuition which I tried to capture in a four-fold table defined by the dimensions of high and low European capacity crossed with high and low national capacity and in which none of the cells was empty (Scharpf, 1999, p. 117). Of particular interest was the quadrant where European solutions were ruled out by the heterogeneity and political 
salience of national interests and preferences, while national solutions were impeded by the legal and economic constraints of European integration. In my view, this field would include the taxation of mobile capital and businesses, macroeconomic employment policy, industrial relations and social policy. In view of the political salience of these policy areas in national democracies, the possibility that European integration might produce a systematic "problemsolving gap' became a major concern of my later work.

Given the joint-decision trap, I never placed much hope on European solutions for these problem areas. Instead, I joined with Vivien Schmidt in a large-scale comparative project to examine national responses to international economic challenges (Scharpf and Schmidt, 2000). We were able to show that countries differed greatly in both their vulnerability to the impacts of economic integration and their institutional capacity to cope with these impacts without abandoning their previous employment and social-policy aspirations. In both regards, Anglo-Saxon and Scandinavian welfare states, though very different from each other, appear to be much better situated than the Continental welfare states. Since the reasons are largely unrelated to my present theme, I will not elaborate them here - except to say that the very generous and expensive Scandinavian model, while immunized against international tax competition by the dual income tax, appears still to be extremely vulnerable to potential extensions of European competition law into the domain of publicly financed social services (Scharpf, 2002; Geyer, 2003).

In other words, the European problem-solving gap exists not only in Continental countries like Italy, France, Belgium and Italy which, unlike the Netherlands, have not yet learned to cope with the challenges of economic integration and liberalization, but it may still spread to Scandinavian welfare states which so far have been able to combine highly competitive open economies with very high levels of employment, very low levels of social inequality and very generous social benefits.

\section{Conclusion: Legitimacy - The Need to Accommodate Diversity}

This brings me to my final point: under the constraints of the joint-decision trap, the European Union will not be able to do much, if anything, about filling the problem-solving gap through European measures of positive integration. Contrary to much of the current rhetoric, the hopes for a common 'European social model' had already become unrealistic after the accession of the United Kingdom in the early 1970s (Ferrera, 2005), and after eastern enlargement one should not even think of reviving them (Sapir, 2006). The same seems to be true of harmonized taxes on capital incomes, of harmonized rules on industrial relations, or of a Keynesian concertation between European monetary policy 
and national fiscal and wage policies (Enderlein, 2004, 2006). European problem-solving capacity could be increased by a switch from unanimous or qualified majority voting to simple majority in the Council. But, as I have argued elsewhere (Scharpf, 1999, 2003), majority decisions that violate politically salient preferences in the Member States would destroy the legitimacy of EU institutions. ${ }^{5}$

The responses of the Parliament and the Council to recent protests against the services directive, or the strike of dock workers, seem to show that politically accountable actors at the European level are aware of these limits of their legitimacy. But legitimacy is also in question when supranational-hierarchical decisions exceed the limits of the permissive consensus which, in the past, has allowed negative integration and EU-imposed liberalization to proceed unopposed. There is as yet nothing in the institutional setting of the EU that would prevent the Commission and the Court from using the instruments of judicial legislation in ways that exceed these limits and that might, at the same time, undermine the legitimacy bases of national welfare states. Moreover, as I said before, even for political decisions in the intergovernmental and joint-decision modes, high consensus requirements can only ensure the legitimacy of initial policy choices. Once European regulations and directives are on the books, they (and their judicial interpretations) are nearly as immune to political reversal as is true of treaty-based ECJ judgments.

In both cases, therefore, EU law may indeed violate politically salient preferences in Member States and may constrain national policy choices in ways that undermine the legitimacy of the political system. Since - after eastern enlargement and the French and Dutch referendums - a general move to simple majority voting is clearly out of the question, it is unlikely that present problems could be resolved through more positive integration. Hence it seems useful to think of other ways in which the stranglehold of existing European law could be sufficiently relaxed to allow more room for manœuvre for national policy choices. ${ }^{6}$ In principle, this could be achieved in one of two ways - either through controlled individual opt-outs or through a modified version of enhanced co-operation.

Both options would take account of the fact that successive rounds of enlargement have progressively increased the diversity of Member State

\footnotetext{
${ }^{5}$ This is not the place for a full discussion of controversies over the democratic (i.e. 'input-oriented' - Scharpf, 1999) legitimacy of the European polity and its policies (e.g. Lord and Magnette, 2004; Schmidt, 2004). In my view, the crucial issue concerns the justification of public policies that violate the highly salient preferences of significant minorities (Scharpf, 2005a). The multiple-veto character of EU policy-making in the intergovernmental and joint-decision modes more or less ensures that policies on which Commission, Council and European Parliament are in fact able to agree, are unlikely to lack legitimacy under this criterion (Moravcsik, 2002). But that would not be so if simple majority voting were introduced and that is by no means ensured when EU policies are adopted in the supranational hierarchical mode.

${ }^{6}$ For a thoughtful and thought-provoking critique of this argument, see Moravcsik (2003).
} 
institutions, economic and social conditions, and political preferences. As a consequence, the 'goodness of fit' of uniform European rules has been generally reduced while a growing body of 'Europeanization' research has documented the high economic, administrative and political costs of compliance with European rules that do not fit (Cowles et al., 2001; Falkner et al., 2004). With the recent accession of central and eastern European Member States plus Cyprus and Malta, and with the imminent inclusion of Bulgaria and Romania, let alone Turkey, the diversity of conditions is increasing to a point where it must defy all aspirations to effectively uniform positive integration (Zielonka, 2006). Given the low level of morale in the present EU, the most likely scenario would combine ever greater difficulties in adopting new legislation with an erosion of the existing acquis through creeping non-compliance and 'institutional hypocrisy' (Iankova and Katzenstein, 2003). In comparison, it might indeed be more attractive to accommodate diversity by allowing explicit departures from uniform European legislation law (Scharpf, 1994).

Opt-outs are of course not unknown in the 'variable geometry' of European integration: not all EU Member States have accepted the Schengen regime, joined monetary union or co-operate in the European security and defence policy. The 'social charter' was adopted in 1989 but did not apply in the UK until 1997 and in each of the successive rounds of enlargement, some of the accession states were granted temporary relief from some provisions of the acquis communautaire. But these are considered exceptions that were either conceded under duress to avoid the veto of an unwilling member government, or that had to be accepted as a temporary expedient in accession negotiations. They were never considered a generally available instrument responding to the tension between a growing body of uniform European law and the increasing diversity of Member State economic and institutional conditions and political preferences.

If opt-outs might allow a fine-tuning of EU legislation to fit the conditions of individual Member States, enhanced co-operation could be adapted to allow the creation of European law that fits the conditions and political preferences of several, but not all, Member States. Such possibilities were first introduced with the Amsterdam Treaty, but even after the modifications adopted in Nice, the rules governing enhanced co-operation have remained so restrictive that the option has never as yet been used. The reason may have been a consequence of unfortunate 'framing': ever since the early 1970s, proponents of a variable geometry have been talking about a hegemonic 'core' group or an avant garde proceeding with 'different speed' towards the ultimate goal of European political and military integration - with the clear implication that all others would find themselves relegated to the rearguard or the periphery. The current terminology avoids these connotations and could be understood to mean that different groups 
of Member States are facing different problems and would benefit from sets of European rules that are designed to fit their specific conditions and preferences (Scharpf, 2002). But distrust is hard to overcome.

Moreover, even when understood without hegemonic implications, distrust may often be justified. The universal enforcement of common rules may be essential for protecting common interests in prisoners' dilemma constellations; individual opt-outs by one Member State may impose negative external effects on its neighbours; and enhanced co-operation may imply protectionism or a denial of solidaristic burden-sharing. It is clear, therefore, that opt-outs and enhanced co-operation could not be granted as a unilateral exit option. It should be equally clear, however, that the present regime rules out solutions to important national problems even where deviations from the acquis would have little or no negative effect on the interests of other Member States or of the Union as a whole. What would be needed, therefore, are rules and procedures for controlled deviation which focus on the merits of the specific case.

Exactly the same problem was faced in recent efforts at federalism reform in Germany - which had finally attempted to open the joint-decision trap by strengthening the autonomy of the Länder in response to growing interregional diversity after German unification (Scharpf, 2005b). As initial demands for a wholesale decentralization of legislative competencies met with strong resistance, it was proposed that the Länder should instead have the right to pass laws displacing or modifying existing federal rules ('Abweichungsrecht'). This proposal was in fact adopted for a few policy areas - with the proviso that a later national statute would again prevail over the deviating Land legislation. ${ }^{7}$ If the solution works in practice, ${ }^{8}$ it may be extended to a wider range of policy areas, allowing the Länder to deal with specific regional problems or to experiment with novel solutions even in areas where the need for national legislation cannot generally be denied.

Given the structural similarities between German federalism and the institutional architecture of the European Union (which had inspired my original article), the institutional innovation introduced in Germany might add to the plausibility of similar proposals at the European level. Since variations in size, economic development, institutional conditions, cultural orientations and political preferences among EU Member States are so much greater than they are among the German Länder, the need to accommodate diversity is also much greater. At the same time, however, increasing international interdependence

\footnotetext{
${ }^{7}$ Arts 72 para. 3 and 84 para. 1 of the Basic Law (Deutscher Bundestag, Drucksache 16/813). The solution does not go very far, but it is at least a step in the direction of more flexible allocation of legislative competencies between national and regional governments. In principle, it would have been possible to extend deviation rights to most areas of federal legislation (Scharpf, 2006).

${ }^{8}$ The most-discussed problem is a danger of 'ping-pong legislation' where a Land law may depart from a federal rule which is then overridden by a later federal statute, from which the Land may deviate again, etc.
} 
and mobility have increased the need for European-level regulations and seem to defy all attempts to generally limit, let alone, reduce the range of EU legislative competencies. Under these conditions, opt-outs and enhanced cooperation appear as useful devices which could respond to national diversity while allowing European legislation to proceed - but only if such deviations must be reviewed and may be controlled at the European level.

In theory, such controls might be left to the Commission and the Court in a modified version of Treaty-violation proceedings. But given their long-standing commitment to maximal Europeanization and the extensive interpretation of Treaty obligations, these institutions would not trusted as neutral arbiters between legitimate European and national concerns. By comparison, peer review in the Council of Ministers seems more likely to achieve a fair balance between the normative commitment to integration and the need to accommodate the legitimate diversity among Member States. ${ }^{9}$ Having voted for the European rule in question, and being suspicious of national beggar-my-neighbour policies, ministers will not lightly accept dubious arguments supporting a need for opt-outs or for enhanced co-operation. But at the same time, ministers may well expect to have to ask for similar concessions on other occasions, and thus will have reason to evaluate national claims with some empathy.

Apart from their obvious potential for accommodating diversity among EU Member States (Scharpf, 2003), these solutions would have two additional benefits. First, the expectation that potential misfits between a European rule and national conditions and preferences might be subsequently modified through individual opt-outs or enhanced co-operation, might greatly reduce opposition to proposed European rules in the first place. As a consequence, majority decisions would be easier to accept, and increasing diversity among Member States may not have quite the damaging impact on positive integration which I would otherwise expect. In other words, we might at least hope for a weakening of the joint-decision trap.

If it were understood, moreover, that deviations from the acquis could also pertain to its interpretation by the European Court of Justice, we might even hope for a cautious politicization of the supranational-hierarchical mode of European governance. It would lose a bit of its dictatorial power as democratically accountable agents at the national and European level would gain the capacity to correct the application of judicial doctrines to specific policy problems that were not determined by the original judgment. ${ }^{10}$ Speaking

\footnotetext{
${ }^{9}$ A possible procedure would require the Member State to notify legislative deviations from the acquis to the Commission before they come into force. The Commission would review the case and submit it to the Council which, within six months after notification, could disallow the national deviation by majority vote. National legislation not so notified would be subject to normal treaty-violations proceedings.

${ }^{10}$ Respect for the judiciary should prevent judgments from being politically reversed in the individual case. What can be subjected to political correction is the generalized rule derived from that judgment.
} 
normatively, that would be a good thing: the powers of judicial legislation in the European polity seem too important, and potentially too damaging, to be left entirely to politically unaccountable bureaucrats and judges. In other words, the weakening of the joint-decision trap would also help to reduce the democratic deficit.

Correspondence:

Fritz W. Scharpf

Max-Planck-Institut für Gesellschaftsforschung

Paulstr. 3

50676 Köln, Germany

email: scharpf@mpi-fg-koeln.mpg.de

\section{References}

Alter, K.J. (1996) 'The European Court's Political Power'. West European Politics, Vol. 19, No. 3, p. 458-87.

Alter, K.J. (2001) Establishing the Supremacy of European Law (Oxford: Oxford University Press).

Börzel, T.A. (2003) 'Guarding the Treaty: The Compliance Strategies of the European Commission'. In Börzel, T.A. and Cichowski, R.A. (eds) The State of the European Union. Law, Politics and Society (Oxford: Oxford University Press).

Buchanan, J.M. and Tullock, G. (1962) The Calculus of Consent. Logical Foundations of Constitutional Democracy (Ann Arbor: University of Michigan Press).

Búrca, G. de (2003) The European Court of Justice and the Evolution of EU Law. In Börzel, T.A. and Cichowski, R.A. (eds) The State of the European Union. Law, Politics and Society (Oxford: Oxford University Press).

Checkel, J.T. (1999) 'Social Construction and Integration'. Journal of European Public Policy, Vol. 6, No. 4, pp. 545-60.

Christiansen, T., Jorgensen, K.E. and Wiener, A. (1999) 'The Social Construction of Europe'. Journal of European Public Policy, Vol. 6, No. 4, pp. 528-44.

Coase, R.H. (1960) 'The Problem of Social Cost'. Journal of Law and Economics, Vol. 3, pp. 1-44.

Cowles, M.G., Caporaso, J.A. and Risse-Kappen, T. (2001) (eds) Europeanization and Domestic Change (Ithaca: Cornell University Press).

Enderlein, H. (2004) 'Break It, Don't Fix It'. Symposium of Reforming Fiscal Policy Co-ordination under EMU. Journal of Common Market Studies, Vol. 42, No. 5, pp. 1039-46.

Enderlein, H. (2006) 'Adjusting to the EMU. The Impact of Monetary Union on Domestic Fiscal and Wage Setting Institutions'. European Union Politics, Vol. 7, No. 1, pp. 37-62.

Enelow, J.M. and Hinich, M.J. (1990) (eds) Advances in the Theory of Spatial Voting (Cambridge: Cambridge University Press). 
Falkner, G., Treib, O., Hartlapp, M. and Leiber, S. (2004) Complying with Europe. EU Harmonization and Soft Law in the Member States (Cambridge: Cambridge University Press).

Ferrera, M. (2005) The Boundaries of Welfare. European Integration and the New Spatial Politics of Social Protection (Oxford: Oxford University Press).

Friend, J.K. and Jessop, W.N. (1969) Local Government and Strategic Choice. An Operational Research Approach to the Processes of Public Planning (London: Tavistock).

Gerber, D.J. (1994a) 'Constitutionalizing the Economy: German Neo-Liberalism, Competition Law, and the "New Europe". American Journal of Comparative Law, Vol. 42, No. 1, pp. 25-84.

Gerber, D.J. (1994b) 'The Transformation of European Community Competition Law'. Harvard International Law Journal, Vol. 35, pp. 97-147.

Gerber, D.J. (2001) Law and Competition in 20th Century Europe. Protecting Prometheus (Oxford: Oxford University Press).

Geyer, R.R. (2003) 'Globalization, Europeanization, Complexity, and the Future of Scandinavian Exceptionalism'. Governance, Vol. 16, No. 4, pp. 559-76.

Hayes-Renshaw, F. and Wallace, H. (1997) The Council of Ministers (Basingstoke: Macmillan).

Hayes-Renshaw, F., van Aken, W. and Wallace, H. (2006) 'When and Why the EU Council of Ministers Votes Explicitly'. Journal of Common Market Studies, Vol. 44, No. 1, pp. 161-94.

Hesse, J.J. and Ellwein, T. (2004) Das Regierungssystem der Bundesrepublik Deutschland (Berlin: De Gruyter).

Iankova, E.A. and Katzenstein, P.J. (2003) 'European Enlargement and Institutional Hypocrisy'. In Börzel, T.A. and Cichowski, R.A. (eds) The State of the European Union. Law, Politics and Society (Oxford: Oxford University Press).

Katzenstein, P.J. (1987) Policy and Politics in West Germany. The Growth of a Semisovereign State (Philadelphia: Temple University Press).

Lax, D.A. and Sebenius, J.K. (1986) The Manager as Negotiator. Bargaining for Cooperation and Competitive Gain (New York: Free Press).

Lewis, J. (2003) 'Institutional Environments and Everyday Decision Making in the European Union'. Comparative Political Studies, Vol. 36, No. 1-2, pp. 97-124.

Lord, C. and Magnette, P. (2004) 'E Pluribus Unum? Creative Disagreement about Legitimacy in the EU'. Journal of Common Market Studies, Vol. 42, No. 1, pp. 183-202.

Moravcsik, A. (1998) The Choice for Europe. Social Purpose and State Power from Messina to Maastricht (Ithaca: Cornell University Press).

Moravcsik, A. (2002) 'In Defence of the "Democratic Deficit": Reassessing Legitimacy in the European Union'. Journal of Common Market Studies, Vol. 40, No. 4, pp. 603-24.

Moravcsik, A. and Sangiovanni, A. (2003) 'On Democracy and "Public Interest" in European Integration'. In Mayntz, R. and Streeck, W. (eds) Die Reformierbarkeit der Demokratie. Innovationen und Blockaden (Frankfurt/M.: Campus). 
Nicolaïdis, K. and Howse, R. (2001) (eds) The Federal Vision. Legitimacy and Levels of Governance in the United States and the European Union (Oxford: Oxford University Press).

Romer, T. and Rosenthal, H. (1978) 'Political Resource Allocation, Controlled Agendas, and the Status Quo'. Public Choice, Vol. 33, pp. 27-43.

Sapir, A. (2006) 'Globalization and the Reform of European Social Models'. Journal of Common Market Studies, Vol. 44, No. 2, pp. 369-90.

Sbragia,A.M. (1993) 'Thinking about the Future: The Uses of Comparison'. In Sbragia, A.M. (ed.) Euro-Politics: Institutions and Policy-making in the 'New' European Community (Washington DC: Brookings).

Scharpf, F.W (1966) 'Judicial Review and the Political Question: A Functional Analysis’. Yale Law Journal, Vol. 75, pp. 517-97.

Scharpf, F.W. (1972) 'Komplexität als Schranke der politischen Planung'. Politische Vierteljahresschrift Sonderheft, No. 4, pp. 168-92.

Scharpf, F.W. (1985) 'Die Politikverflechtungs-Falle: Europäische Integration und deutscher Föderalismus im Vergleich'. Politische Vierteljahresschrift, Vol. 26, No. 4, pp. 323-56.

Scharpf, F.W. (1988) 'The Joint-decision trap: Lessons from German Federalism and European Integration'. Public Administration, Vol. 66, pp. 239-78.

Scharpf, F.W. (1994) 'Community and Autonomy. Multilevel Policy-Making in the European Union'. Journal of European Public Policy, Vol. 1, No. 2, pp. 219-42.

Scharpf, F.W. (1996) 'Negative and Positive Integration in the Political Economy of European Welfare States'. In Marks, G., Scharpf, F.W., Schmitter, P.C. and Streeck, W. (eds) Governance in the European Union (London: Sage).

Scharpf, F.W. (1997) Games Real Actors Play. Actor-Centred Institutionalism in Policy Research (Boulder, CO: Westview).

Scharpf, F.W. (1999) Governing in Europe. Effective and Democratic? (Oxford: Oxford University Press).

Scharpf, F.W. (2001) 'Notes Toward a Theory of Multilevel Governing in Europe'. Scandinavian Political Studies, Vol. 24, No. 1, pp. 1-26.

Scharpf, F.W. (2002) 'The European Social Model: Coping With the Challenges of Diversity'. Journal of Common Market Studies, Vol. 40, No. 4, pp. 645-70.

Scharpf, F.W. (2003) 'Legitimate Diversity: The New Challenge of European Integration'. Zeitschrift für Staats- und Europawissenschaften, Vol. 1, No. 1, pp. 32-60.

Scharpf, F.W. (2005a) 'Legitimationskonzepte jenseits des Nationalstaats'. In Schuppert, G.F., Pernice, I. and Haltern, U. (eds) Europawissenschaft (Baden-Baden: Nomos).

Scharpf, F.W. (2005b) 'No Exit from the Joint-Decision Trap? Can German Federalism Reform Itself?'. MPIfG Working Paper 05/08. Cologne, Max Planck Institute for the Study of Societies, available at «http://www.mpi-fg-koeln.mpg.de/pu/workpap/ wp05-8/wp05-8.html».

Scharpf,F.W. (2006) ‘Nicht genutzte Chancen derFöderalismusreform'. MPIfG Working Paper 06/02. Cologne: Max Planck Institute for the Study of Societies, available at «http://www.mpi-fg-koeln.mpg.de/pu/workpap/wp06-2/wp06-2.html». 
Scharpf, F.W. and Schmidt, V.A. (2000) (eds) Work and Welfare in the Open Economy (Oxford: Oxford University Press).

Scharpf, F.W., Reissert, B. and Schnabel, F. (1976) Politikverflechtung: Theorie und Empirie des kooperativen Föderalismus in der Bundesrepublik (Kronberg/Ts.: Scriptor).

Schmidt, M.G. (2003) Political Institutions in the Federal Republic of Germany (Oxford: Oxford University Press).

Schmidt, S.K. (1998) Liberalisierung in Europa. Die Rolle der Europäischen Kommission (Frankfurt a.M.: Campus).

Schmidt, S.K. (2000) 'Only an Agenda Setter? The European Commission's Power over the Council of Ministers'. European Union Politics, Vol. 1, No. 1, pp. 37-62.

Schmidt, S.K. (2002) 'The Impact of Mutual Recognition. Inbuilt Limits and Domestic Responses'. Journal of European Public Policy, Vol. 9, No. 6, p. 935-53.

Schmidt, V.A. (2004) 'The European Union: Democratic Legitimacy in a Regional State'. Journal of Common Market Studies, Vol. 42, No. 5, pp. 975-97.

Sinn, H-W. and Ochel, W. (2003) 'Social Union, Convergence and Migration'. Journal of Common Market Studies, Vol. 41, No. 5, pp. 869-96.

Stone Sweet, A. (2003) 'European Integration and the Legal System'. In Börzel, T.A. and Cichowski, R.A. (eds) The State of the European Union. Law, Politics and Society (Oxford: Oxford University Press).

Tsebelis, G. (1994) 'The Power of the European Parliament as a Conditional Agenda Setter'. American Political Science Review, Vol. 88, pp. 128-42.

Tsebelis, G. (1995) 'Decision-Making in Political Systems: Veto Players in Presidentialism, Parliamentarism, Multicameralism, and Multipartyism.' British Journal of Political Science, Vol. 25, pp. 289-326.

Tsebelis, G. (2002) Veto Players. How Political Institutions Work (Princeton: Princeton University Press).

Tsebelis, G. and Yataganas, X. (2002) 'Veto Players and Decision-making in the EU After Nice. Policy Stability and Bureaucratic/Judicial Discretion'. Journal of Common Market Studies, Vol. 40, No. 2, pp. 283-307.

Weiler, J.H.H. (1982) 'The Community System: The Dual Character of Supranationalism'. Yearbook of European Law, Vol. 1, pp. 257-306.

Zielonka, J. (2006) Europe as Empire. The Nature of the Enlarged European Union (Oxford: Oxford University Press). 